\title{
Seedling establishment and regeneration in a harvested Eucalyptus plantation at Maragamuwa, Naula, Sri Lanka
}

\author{
K.B. Ranawana ${ }^{1, *}$, T. M. Reed ${ }^{2}$ and H.W.G.S. Yasarathne ${ }^{3}$ \\ ${ }^{1}$ Department of Zoology, University of Peradeniya, Sri Lanka \\ ${ }^{2}$ TREC Ltd, 4 Cromwell Terrace, St Ives, Cambs, PE27 5JE, UK. \\ ${ }^{3 .}$ Bamunawala, Kurunegala, Sri Lanka
}

\begin{abstract}
The first year of secondary succession in a harvested Eucalyptus camaldulensis plantation near Maragamuwa village, Naula, was examined to see the possible effect of distance from the adjacent relatively undisturbed mature forest on the form and composition of natural regeneration after removal of eucalypts. Composition, relative densities and absolute abundance were examined in cleared 40, 20 $\times 20 \mathrm{~m}^{2}$ quadrats placed in eight 1 ha blocks in two types of locations: harvested eucalypt plantation away from the natural forest (MP) and harvested blocks next to the natural forest (MT), and compared with 20 similar sized quadrats sampled in the adjacent mature forest (NF). Relative density values for MT and MP were compared with the adjacent NF using KruskalWallis and Mann-Whitney U tests. A total of 11,207 individuals from 77 species were recorded per hectare in MP, while 11,658 individuals/ha from 61 species were recorded from MT and 5,925 individuals/ha from 39 species in NF. Relative densities of seedlings in MP and MT were significantly different from NF ( $p$ < 0.05$)$. There was no significant difference between the relative densities of seedlings in MT and MP $(p>0.05)$. Most individuals in MP and MT were $1-100 \mathrm{~cm}$ tall. Species composition suggests the basis for seral succession, with the cleared and distant MP plots having most non-forest species, and a high abundance per species compared with the MT plots adjacent to the mature forest. Natural forest plots had fewer individuals in each family or species, and a far lower density of the lianas typical of the first stages of colonization. In the first year of succession, there were indications of a distance effect in blocks adjacent to forest sites.
\end{abstract}

Keywords: vegetation structure, floristic composition, succession, natural forest.

\section{INTRODUCTION}

Eucalyptus spp. have been widely planted in tropical and subtropical regions as fast-growing timber trees (Munasinghe, 2003). With the right species in the right soil, under suitable climatic conditions, Eucalyptus can rapidly grow stands of good quality timber (Timothy et al., 2004) and trees could be harvested during early years (within 7-8 years) for getting more income per annum (Tanvir et al., 2002). Eucalyptus camaldulensis Dehnh is the most commonly planted eucalypt in the semi dry areas of Sri Lanka (Vivekanandan, 1979), though not all plantations have been successful (Perera, 1998) with many suffering from limited growth due to thin soils, the relatively dry climate, and due to their vulnerability to periodic flash fires common in the agricultural areas.

Eucalypts are one of the most widespread and problematic alien tree species in Sri Lanka, and have become the focus of government attention (Reed et al., 2009). Although widely planted for timber, their success has been mixed at best (Reed et al., 2009). Because of their impacts on biodiversity, water resources and ecosystem services, the management and recovery of thousands of hectares under failing eucalypts back to native forest is now of especial interest to foresters and researchers, as well as to the Sri Lankan Government (Bandaratillake, 1996).

Monocultural plantations, such as eucalypt, support poorer species assemblages than biologically diverse natural forests (Bandaratillake, 1996). Colonization of natural tree species in degraded habitats in the Intermediate Zone of the country is poorly understood (Perera, 2001). The restoration of degraded habitats using the Assisted Natural Regeneration (ANR) process is an emerging trend all over the world (Shono et al., 2007). 
One of the reasons for initiating this long-term research in a harvested eucalypt plantation in Naula is to assess the best (and low cost) ANR restoration methods suitable for degraded lands in the Intermediate climatic zone of Sri Lanka. The current study reports on the first year of monitoring of plots cleared of eucalypts, and provides a baseline for changes in biodiversity and the possible effect of distance from the adjacent native forest on the colonization of cleared plots.

\section{MATERIALS AND METHODS}

\section{Study Site}

The Maragamuwa Forest Regeneration Study Site (FRSS) $\left(7^{0} 41^{\prime} 39.16^{\prime \prime} \mathrm{N}-80^{\circ} 42^{\prime} 31.58^{\prime \prime} \mathrm{E}\right)$ is located near Maragamuwa village, bordering the Naula - Elahera trunk road in Matale district, Sri Lanka. The FRSS was established in a 60 ha block of an eucalypt plantation, managed until 2005 to provide fuel wood used in the curing of tobacco by the Ceylon Tobacco Company (CTC). The FRSS was part of a block of land leased by CTC for a 30 year period by the Forest Department of Sri Lanka. After switching to paddy husk as an alternative fuel, the CTC established the FRSS at Maragamuwa plantation block in 2005, in order to revert the stand back to a native forest using Assisted Natural Regeneration.

The FRSS is located in the intermediate climate zone at an elevation $369 \mathrm{~m}$ above sea level, with a mean annual rainfall of $1,750 \mathrm{~mm}$ to $2,250 \mathrm{~mm}$, and a mean annual temperature of $27^{\circ} \mathrm{C}$. It is part of the Kumaragala Forest reserve, a conservation forest managed by the Forest Department of Sri Lanka.

The natural forest bordering the FRSS plantation is a dry mixed evergreen forest, typical of the semi dry zone of Sri Lanka (Perera 2001). The soils are Reddish Brown Laterites (Panabokke, 1996), formed under an annual regime of two short wet periods in October to
February (Major wet season) and in April (Minor wet season) and a long dry period. The western side of the study site borders little-disturbed native forest (Kumaragala Forest Reserve), while the rest of the plantation is surrounded by home gardens and chena lands (slash and burn cultivation) (Figure 1).

\section{Preparation of study sites}

In order to understand the patterns of colonization, and factors influencing the development of forest and its associated biodiversity, eight 1 ha blocks were selected at different distances from the forest edge in 2005 (Figure 1). Four (labelled as Plantation Blocks, MP) were cleared in the centre of the plantation, whilst four (labelled as Transition Blocks, MT) were cleared on the border of the mature forest. Only the Eucalyptus trees were felled. All cut woody material was removed from each area, in order to ensure that there were no surface obstructions limiting the colonization. Each block was subdivided into $20 \mathrm{~m} \times 20 \mathrm{~m}$ subplots. For monitoring purposes, five subplots were randomly chosen in each block. In addition, 20 similar-sized plots were sampled in the mature forest (NF) for comparison.

One of the attractions of E. camaldulensis for fuel harvesting is its ability to regrow from coppice stools, as trees are cut down to the ground. In order to control the potential effects of eucalypt regrowth, all coppice stools were killed by light exclusion (Reed et al., 2009), so that the effects of their regrowth would not affect plant recolonization. In addition, the blocks were protected from fire by fire breaks on three sides (except for the side nearest to the forest), and domestic stock were fenced out. 


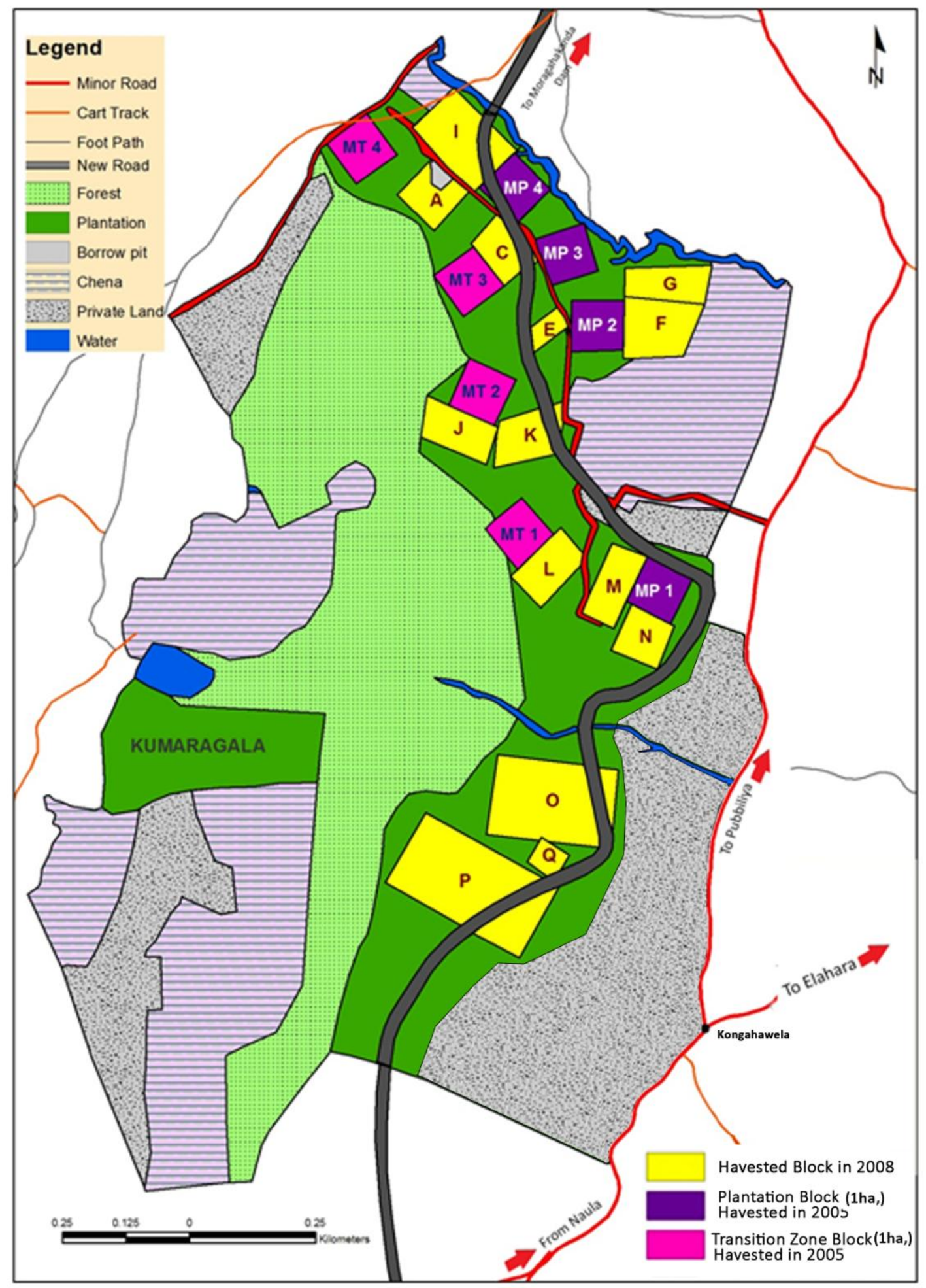

Figure 1: Map of Maragamuwa Forest Regeneration Study Site (FRSS). 


\section{Vegetation Sampling}

\section{Establishment of Experimental Plots}

After the clearance of eucalypts from MP and MT plots in May, 2005, the non-herbaceous vegetation was sampled in May, 2006. All nonherbaceous plant were classed as either tree, shrub or liana, and heights and abundance of all seedlings in each subplot were counted and their abundance was recorded. Each seedling was given a number, and tagged with an Aluminium label. Each numbered tag was recorded with the family, scientific name and common local name and used to track their subsequent life histories. Herbarium sheets were prepared for all recorded plant species. All specimens were identified to the species level, and the number of individuals of each was counted. Those which were difficult to identify were checked using herbarium sheets available in the National Herbarium, Peradeniya. Specimens were authenticated using the standard checklist of the flora of Ceylon (Senaratne, 2001).

\section{Data analysis}

Relative densities of tree species were calculated and compared in three plot types (MP, MT, NF). Data was analyzed using non-parametric statistical tests, since the data was not normally distributed. The Kruskal-Wallis Test (Gibbons and Chakraborti, 2003) was used to test whether there was a significant difference between the relative densities of trees, shrubs and lianas in the three plot types. Mann-Whitney $U$ test (Gibbons and Chakraborti, 2003) was used to see which plot types, if any, were significantly different from the others.

Diversity indices for species richness (Simpson Diversity Index (1-D), species abundance (Shannon Diversity Index $\left(\mathrm{H}^{\prime}\right)$, and dominance (Berger Parker Index (d)) were compared between plot types (Magurran, 1988).

\section{RESULTS}

\section{Floristic composition and species diversity}

Higher seedling densities were recorded from both MP and MT plots than NF plots (Table 1). Species richness was highest in the more open MP plots (31) followed by MT plots (28) and NF plots (21). Most of the seedlings in MP and MT were either pioneer or under-storey species, in contrast to NF with its tree-dominated canopy and more limited ground level vegetation (Appendices I - III). The highest abundance of trees, small trees and lianas were also found in MP (Table 2).

Table 1: Summary of the non-herbaceous plant data recorded from study plots at Maragamuwa Forest Regeneration Study site.

\begin{tabular}{|c|c|c|c|c|}
\hline Plot type & $\begin{array}{c}\text { No. of } \\
\text { individuals } \\
\text { per ha }\end{array}$ & $\begin{array}{c}\text { Mean no.of } \\
\text { individuals per } \\
20 \times 20 \mathrm{~m}^{2} \text { quadrat }\end{array}$ & No. of families & No.of species \\
\hline MP & 11,207 & 448 & 31 & 77 \\
\hline MT & 11,658 & 466 & 28 & 61 \\
\hline $\mathrm{NF}$ & 5,925 & 237 & 21 & 39 \\
\hline
\end{tabular}

Table 2: Life form categories of the plant species recorded in study plots.

\begin{tabular}{ccccc}
\hline Plot type & No. of trees* & No.of small trees* & No.of shrubs & No. of liana \\
\hline MP & 38 & 24 & 8 & 7 \\
MT & 32 & 18 & 4 & 7 \\
NF & 17 & 13 & 1 & 8
\end{tabular}

*Categories are based on final expected life form: Appendix 1 (Ashton et al., 1997). 
Pterospermum suberifolium showed the highest seedling density in both MP and MT, followed by Grewia damine (Appendix III). Higher relative seedling densities of small tree species such as Glycosmis pentaphylla, Streblus taxoides, Streblus asper, and Glycosmis angustifolia were also recorded in MP rather than in MT (Appendix II). Densities of common pioneer or early climax species, such as Streblus taxoides, Streblus asper and Glycosmis angustifolia, were highest in the more open MP. In MT, late climax species such as Dimocarpus longan and Chloroxylon swietenia were more common than in the distant MP plots. Catunaregam spinosa was most abundant shrub species in the MP plots, and was slightly more abundant than in MT; it was absent from MF plots (Appendix II). Liana densities, classic indicators of secondary forest colonization and openness (Richards 1952), were highest in MP and MT (Appendix I).

Pair-wise comparison test showed that seedling density was significantly different between plots $(p<0.05)$. Mann-Whitney $U$ test showed that seedling density of MP and MT were not significantly different from each other but differ from NF (Table 3).

Diversity values for MP and MT plots were almost similar (Table 4), but differed from NF. Shannon diversity, evenness and Simpson diversity values were higher in NF than MP or MT plots. Berger-Parker dominance value was lowest in the NF plots.

\section{DISCUSSION}

A secondary forest can be recognized by its floristic composition, than its physiognomy (Perera, 2001). In the first year after clear felling, MP and MT plots were dominated by Pterospermum suberifolium and Grewia damine (Appendix II), both of which are early colonizing species in the dry zone of Sri Lanka following disturbances (Perera, 2001). Both were found in very low densities in NF plots (Appendix II). Regenerating forests (MP and MT) are full of light demanding early colonizers, the majority of which are readily dispersed by wind or birds (Troup 1921; Daniel and Aldicir, 2006). Some of these species were completely absent in NF plots. Similarly, small tree species (Ashton et $a l, 1997)$ such as Streblus asper and Glycosmis pentaphylla, typical of disturbed areas, were more abundant in the MP and MT plots than in the NF plots (Appendix III).

Richards (1952) noted that in Malaya, the pioneers of secondary forests come from a limited number of families including Euphorbiaceae, Lauraceae and Urticulaceae. At Maragamuwa, MT was dominated by Euphorbiaceae, Rutaceae, Sterculiaceae and Fabaceae, whilst in MP the most abundant families were Fabaceae, Sterculiaceae, Rutaceae, Moraceae and Tiliaceae. By contrast, NF was dominated by Anacardiaceae, Annonaceae, Euphorbiaceae and Sapindaceae: typically lateclimax species. Many of the species in the open MP plots, furthest away from the forest edge, were early seral species (Appendices II-III), whilst those in MT, much closer to the forest edge, were more typical of mid-late succession species. Early seral forest colonists tend to be superabundant, giving way to the less abundant, more shade-tolerant colonists over time (Richards, 1952). A simple examination of the average number of species and families and individuals in NF, MT and MP (Table 1) indicated a decline in abundance of species and families towards the forest edge away from the cleared plots. The number of individuals per species or family was higher in MP than MT or $\mathrm{NF}$, suggesting increased dominance of progressively fewer species with distance from the forest edge, contrasted with higher diversity, and fewer individuals, confirmed by the Bergman-Parker index, towards the mature forest. After a short span of clearance of eucalypts, the results clearly showed that tree, shrub and liana colonization is rapid and dynamic, and patterns were beginning to emerge: both in composition and abundance, an indicative of distance-dependent recovery.

\section{ACKNOWLEDGEMENTS}

The authors express their gratitude to the Ceylon Tobacco Company for granting permission to carry out this work in an Eucalyptus plantation managed by the Company. Also the authors would like to thank Ms. Chathurika Munasinghe for her assistance in data analysis and $\mathrm{Mr}$. Sanjeewa Jayarathne for field assistance and data compilation. 
Table 3: Summary of the results of Mann-Whitney U test.

$\begin{array}{lll}\text { Comparison of Relative Densities } & \text {-value } & \begin{array}{l}\text { Interpretation at } \\ \text { significance level. }\end{array} \\ \text { between Plot Types } & \text { s\% }\end{array}$

\begin{tabular}{lll}
\hline NF $v s$ MP & 0.0005 & Significant \\
NF $v s$ MT & 0.0205 & Significant \\
MP $v s$ MT & 0.4888 & Not significant \\
\hline
\end{tabular}

Table 4: Diversity and evenness indices among different vegetation types.

\begin{tabular}{lccc}
\hline Index & MP & MT & NF \\
\hline Shannon index (H') & 2.64 & 2.64 & 2.89 \\
Shannon evenness (E) & 0.608 & 0.642 & 0.789 \\
Simpson index (1-D) & 0.871 & 0.871 & 0.924 \\
Berger-Parker index (d) & 0.283 & 0.283 & 0.134 \\
\hline
\end{tabular}

\section{REFERENCES}

Ashton, M. S., Gunatilleke, S., de Zoysa, N., Dassamayake, M. D., Gunatilleke, N. and S. Wijisundera. (1997). A field guide to the common trees and shrubs of Sri Lanka. WHT Colombo.

Bandaratillake, H.M. (1996). Eucalyptus Plantations in Sri Lanka: Environmental, Social,

Economic and Policy Issues. In: Reports submitted to the regional expert consultation on eucalyptus. Volume II. RAP PUBLICATION: 1996/44. FAO Regional Office for Asia and the Pacific (RAP) Bangkok, Thailand; 23pp.

Daniel, L. M and Aldicir, S. (2006). Principles of Natural Regeneration of Tropical Dry Forests for Restoration Restoration Ecology. 14, No. 1, pp. 11-20.

Gibbons, J. D. and Chakraborti, S. (2003). Non parametric Statistical Inference. Fourth Edition. Marcel Dekker, Inc. 164-173.

Munasinghe, J.E. (2003). State of Forest Genetic Resources Conservation and Management in Sri Lanka. Forest Genetic Resources Working Papers. In: Working Paper FGR/66E. Forest Resources Development Service, Forest Resources Division. FAO, Rome. pp. 1-27.

Panabokke,C.R.(1996). Soils and agro-ecological environment of Sri Lanka. Natural Resource Series No.2.pp220.Natural Resource Energy\& Science Authority. Colombo, Sri Lanka

Perera, G.A.D. (1998). Commercial viability of forest plantations in Sri Lanka. In: Proceedings of the fourth annual forestry and environment symposium 1998.University of Sri Jayewardenepara. pp: 30.
Perera, G. A. D (2001). The Secondary Forest Situation in Sri Lanka. Journal of Tropical Forest Science 13: 768-785.

Reed, T. M , Ranawana, K. B. and Nanayakkara, A. (2009). Methods tested, and their costs, to control re-growth of coppiced Eucalyptus camaldulensis in harvested plantations in Naula, Matale District, Sri Lanka. Ceylon Journal of Science (Bio. Sci.) 38 (2): 75-82.

Richards, P.W. (1952). Tropical Rain Forests. First Edition. Cambridge University press, London: xviii+450 pp.

Senaratna,L.K. (2001). A check list of the flowering plants of Sri Lanka. National Science Foundation, Colombo 7, Sri Lanka.

Shono, K., Cadaweng, E. A., and Durst, P.B. (2007). Application of Assisted Natural Regeneration to restore degraded tropical forestlands. Restoration Ecology 15 (4): 620-626.

Tanvir, M.A., Siddiqui, M.T. and Shah, A.H. (2002). Growth and Price Trend of Eucalyptus camaldulensis in Central Punjab. International Journal of Agriculture Biology 4 (3): 344-346.

Timothy A. Volk, T. , Pradeep, V., Tharakan, J., Abrahamson, L.P. and White, E.H. (2004). Growing fuel: a sustainability assessment of willow biomass crops. Frontiers in Ecology and the Environment 2: 411- 418.

Troup, R.S. (1921). The Silviculture of Indian Trees. Third volume. The Clarendon Press, Oxford, London.

Vivekanadan, K. (1979). Performance of provenances of Eucalyptus in Sri Lanka. Sri Lanka Forester 14:49-54.

Magurran, A.E. (1988). Ecological diversity and its measurement. Croom Helm Limited, London, $\mathrm{x}$ $+179 \mathrm{p}$. 
Appendix I: Relative densities of liana species recorded from the study sites.

\begin{tabular}{|c|c|c|c|c|c|c|}
\hline \multirow[b]{2}{*}{ Family } & \multirow[b]{2}{*}{ Species } & \multirow[b]{2}{*}{ Common Name } & \multirow[b]{2}{*}{$\mathrm{NCS}^{1}$} & \multicolumn{3}{|c|}{ Relative Density (\%) } \\
\hline & & & & NF & MT & MP \\
\hline Apocynaceae & Aganosma cymosa & Muwa-Kiri-Wel & LC & 0.67 & 0.17 & 0.14 \\
\hline Capparidaceae & Capparis sp. & Wellangiriya & & 0.45 & 0.40 & 0.19 \\
\hline Fabaceae & Derris trifoliata & Kalawel & $\mathrm{LC}$ & 1.25 & 14.35 & 13.94 \\
\hline Hippocrateaceae & $\begin{array}{l}\text { Salacia reticulata } \\
\text { Ventilago }\end{array}$ & Himbutu & EN & 2.08 & 2.49 & 2.65 \\
\hline Rhamnaceae & madraspatana & $\begin{array}{l}\text { Yakadawal } \\
\text { Eraminiya / Heen }\end{array}$ & LC & 0.67 & - & 0.03 \\
\hline Rhamnaceae & Ziziphus oenoplia & Eraminiya & $\mathrm{LC}$ & 0.08 & 2.19 & 1.30 \\
\hline Tiliaceae & Grewia orientalis & Keliya & $\mathrm{LC}$ & 0.16 & 3.05 & 6.16 \\
\hline Vitaceae & Cayratia pedata & Mediyawel & $\mathrm{LC}$ & 0.16 & 0.20 & - \\
\hline
\end{tabular}

${ }^{1}$ National Conservation Status (follows, MOE, 2012)

EN - Endangered; LC - Least concerned 
Appendix II: Relative densities of shrub species recorded from the study sites.

\begin{tabular}{|c|c|c|c|c|c|c|}
\hline \multirow[b]{2}{*}{ Family } & \multirow[b]{2}{*}{ Species } & \multirow[b]{2}{*}{ Local Name } & \multirow[b]{2}{*}{$\mathrm{NCS}^{1}$} & \multicolumn{3}{|c|}{ Relative Density (\%) } \\
\hline & & & & NF & MT & MP \\
\hline Apocynaceae & Carissa spinarum & Heen-Karamba & LC & - & - & 0.01 \\
\hline Euphorbiaceae & Phyllanthus polyphyllus & Kuratiya & $\mathrm{LC}$ & - & - & 0.01 \\
\hline Flacourtiaceae & Casearia tomentosa & Kiri Makulu & NT & - & - & 0.01 \\
\hline Myrsinaceae & Maesa indica & Matibabiya & $\mathrm{LC}$ & - & 0.03 & 1.63 \\
\hline Rubiaceae & Catunaregam spinosa & Kukuruman & $\mathrm{LC}$ & - & 2.74 & 6.06 \\
\hline Rubiaceae & Mussaenda frondosa & Butsarana & & - & - & 0.02 \\
\hline Rubiaceae & Psilanthus wightianus & - & VU & - & 2.76 & 0.18 \\
\hline Rutaceae & Atalantia ceylanica & Yakinaran & $\mathrm{LC}$ & 0.11 & 0.07 & 0.13 \\
\hline
\end{tabular}

${ }^{1}$ National Conservation Status (follows, MOE, 2012)

VU- Vulnerable

NT - Near Threatened; LC - Least Concerned 
Appendix III: Relative densities of tree and small tree species recorded from the study sites.

\begin{tabular}{|c|c|c|c|c|c|c|c|}
\hline \multirow[b]{2}{*}{ Family } & \multirow[b]{2}{*}{ Species } & \multirow[b]{2}{*}{ Life Form* } & \multirow[b]{2}{*}{ Common Name } & \multirow[b]{2}{*}{$\mathrm{NCS}^{1}$} & \multicolumn{3}{|c|}{ Relative Density (\%) } \\
\hline & & & & & NF & MT & MP \\
\hline Alangiaceae & Alangium salviifolium & Small tree & Math anguna & NT & - & 0.26 & 0.18 \\
\hline Amaranthaceae & Digera muricata & Tree & Tigol & NT & - & - & 0.01 \\
\hline Anacardiaceae & Nothopegia beddomei & Tree & Bala & & 6.78 & 0.10 & - \\
\hline Annonaceae & Polyalthia korinti & Small tree & Ulkenda & $\mathrm{LC}$ & 6.80 & 0.77 & 0.16 \\
\hline Annonaceae & Annona cherimola & Tree & Anoda & & - & 0.01 & - \\
\hline Annonaceae & Miliusa indica & Tree & Kekilimassa & & 3.01 & 0.03 & - \\
\hline Bignoniaceae & Stereospermum colais & Tree & Dunumadala & $\mathrm{LC}$ & - & 0.01 & 0.03 \\
\hline Boraginaceae & Carmona retusa & Small tree & Heen-tambala & $\mathrm{LC}$ & 6.03 & 1.23 & 0.11 \\
\hline Boraginaceae & Cordia dichotoma & Tree & Lolu & $\mathrm{LC}$ & - & 0.06 & 0.07 \\
\hline Capparidaceae & Capparis brevispina & Small tree & Waldehi & NT & 1.68 & 0.74 & 0.39 \\
\hline Capparidaceae & Capparis zeylanica & Small tree & Sudu-Welangiriya & $\mathrm{LC}$ & 0.16 & - & - \\
\hline Clusiaceae & Garcinia spicata & Tree & Gonna / Ela-Gokatu & NT & - & - & 0.01 \\
\hline Ebenaceae & Diospyros ovalifolia & Small tree & Habara/ Kunumella & $\mathrm{LC}$ & - & - & 0.01 \\
\hline Ebenaceae & Diospyros ebenoides* & Tree & Ilapath-habaraliya & & - & - & 0.06 \\
\hline Ebenaceae & Diospyros ebenum & Tree & Kaluwara & EN & 2.75 & 0.17 & 0.06 \\
\hline Euphorbiaceae & Dimorphocalyx glabellus & Small tree & Weliwenna & $\mathrm{LC}$ & 3.20 & 0.94 & 1.39 \\
\hline Euphorbiaceae & Blachia umbellata & Tree & Goda-Rathmal & $\mathrm{LC}$ & 0.03 & - & 0.03 \\
\hline Euphorbiaceae & Bridelia retusa & Tree & Ketakala & $\mathrm{LC}$ & - & 0.29 & 0.89 \\
\hline Euphorbiaceae & Croton laccifer & Tree & Gas-eppetiya & $\mathrm{LC}$ & - & - & 0.07 \\
\hline Fabaceae & Cassia fistula & Small tree & Ehala & & - & - & 0.01 \\
\hline Fabaceae & Leucaena leucocephala & Small tree & Ipil Ipil & & - & - & 0.07 \\
\hline Fabaceae & Pongamia pinnata & Small tree & Gal-Karanda & $\mathrm{LC}$ & - & - & 0.03 \\
\hline Flacourtiaceae & Scolopia acuminata & Small tree & Katukenda & $\mathrm{LC}$ & 0.19 & 0.03 & 0.00 \\
\hline Leeaceae & Leea indica & Small tree & Burulla & $\mathrm{LC}$ & - & - & 0.01 \\
\hline Melastomataceae & Memecylon umbellatum & Small tree & Korakaha & & - & 0.19 & 0.23 \\
\hline Meliaceae & Cipadessa baccifera & Small tree & Halbambiya & $\mathrm{LC}$ & 0.27 & 6.76 & 0.91 \\
\hline Moraceae & Streblus asper & Small tree & Netul & $\mathrm{LC}$ & - & 1.57 & 5.64 \\
\hline Moraceae & Streblus taxoides & Small tree & Katupol / Gon gotu & $\mathrm{LC}$ & 0.29 & 0.19 & 7.02 \\
\hline Myrtaceae & Eugenia bracteata & Small tree & Daduwaha & & - & 0.71 & 0.36 \\
\hline
\end{tabular}


Appendix III ctd.

\begin{tabular}{|c|c|c|c|c|c|c|c|}
\hline \multirow[b]{2}{*}{ Family } & \multirow[b]{2}{*}{ Species } & \multirow[b]{2}{*}{ Life Form* } & \multirow[b]{2}{*}{ Common Name } & \multirow[b]{2}{*}{$\mathrm{NCS}^{1}$} & \multicolumn{3}{|c|}{ Relative Density (\%) } \\
\hline & & & & & $\begin{array}{c}\text { Natural } \\
\text { Forest }\end{array}$ & $\begin{array}{c}\text { Transition } \\
\text { Zone }\end{array}$ & Planation \\
\hline Rubiaceae & Canthium coromandelicum & Small tree & Kara & $\mathrm{LC}$ & 0.03 & 0.14 & 0.25 \\
\hline Rutaceae & Glycosmis angustifolia & Small tree & Bolpana & $\mathrm{LC}$ & 2.11 & 0.10 & 4.56 \\
\hline Rutaceae & Glycosmis pentaphylla & Small tree & Dodanpana & $\mathrm{LC}$ & 0.08 & 5.36 & 9.45 \\
\hline Rutaceae & Pleiospermium alatum & Small tree & Thunpath-kurudu & $\mathrm{LC}$ & 0.08 & 0.20 & 0.07 \\
\hline Sapindaceae & Allophylus cobbe & Small tree & Kobbe & $\mathrm{LC}$ & - & 0.10 & 0.37 \\
\hline Verbenaceae & Gmelina asiatica & Small tree & Debata & $\mathrm{LC}$ & - & 0.07 & 0.94 \\
\hline Verbenaceae & Premna latifolia & Small tree & Galkara / Maha midi & $\mathrm{LC}$ & - & - & 0.01 \\
\hline Euphorbiaceae & Drypetes sepiaria & Tree & Veera & $\mathrm{LC}$ & 3.47 & - & - \\
\hline Euphorbiaceae & Macaranga peltata & Tree & Kenda & $\mathrm{LC}$ & 0.03 & 0.14 & 0.21 \\
\hline Euphorbiaceae & Mallotus philippensis & Tree & Hampirilla & & 1.73 & 28.35 & 0.19 \\
\hline Fabaceae & Bauhinia racemosa & Tree & Maila & $\mathrm{LC}$ & - & 0.03 & 0.14 \\
\hline Fabaceae & Cassia spectabilis & Tree & Kaha kone & & - & - & 0.02 \\
\hline Flacourtiaceae & Flacourtia indica & Tree & Walugurassa & $\mathrm{LC}$ & - & 0.24 & 1.59 \\
\hline Lauraceae & Litsea glutinosa & Tree & Bomee & $\mathrm{LC}$ & - & 0.07 & 0.02 \\
\hline Meliaceae & Azadirachta indica & Tree & Kohomba & & - & - & 0.01 \\
\hline Meliaceae & Chukrasia tabularis & Tree & Hulanhik & NT & - & 0.01 & 0.02 \\
\hline Meliaceae & Melia azedarach & Tree & Lunumidella & & - & - & 0.06 \\
\hline Meliaceae & Walsura trifoliolata & Tree & Kirikone & $\mathrm{LC}$ & 0.56 & 0.09 & 0.08 \\
\hline Moraceae & Broussonetia zeylanica* & Tree & Alandu & VU & - & 0.06 & 0.02 \\
\hline Myrtaceae & Syzygium gardneri & Tree & Damba & $\mathrm{LC}$ & - & 0.06 & - \\
\hline Olacaceae & Olax imbricata & Tree & Thelatiya & & - & 0.01 & 0.01 \\
\hline Rubiaceae & Haldina cordifolia & Tree & Kolon & $\mathrm{LC}$ & - & 0.03 & 0.04 \\
\hline Rubiaceae & Ixora pavetta & Tree & Bulath-karaw & $\mathrm{LC}$ & - & 0.10 & 0.06 \\
\hline Rutaceae & Acronychia pedunculata & Tree & Ankenda & $\mathrm{LC}$ & 0.03 & - & - \\
\hline
\end{tabular}


Appendix III ctd.

\begin{tabular}{|c|c|c|c|c|c|c|c|}
\hline \multirow[b]{2}{*}{ Family } & \multirow[b]{2}{*}{ Species } & \multirow[b]{2}{*}{ Life Form* } & \multirow[b]{2}{*}{ Common Name } & \multirow[b]{2}{*}{ NCS $^{1}$} & \multicolumn{3}{|c|}{ Relative Density (\%) } \\
\hline & & & & & Natural Forest & Transition Zone & Planation \\
\hline Rutaceae & Chloroxylon swietenia & Tree & Burutha & VU & 0.21 & 2.37 & 1.47 \\
\hline Rutaceae & Pamburus missionis & Tree & Galpaderuwa/Pamburu & & - & 0.41 & - \\
\hline Sapindaceae & Dimocarpus longan & Tree & Mora & LC & 1.60 & 1.12 & 0.68 \\
\hline Sapindaceae & Lepisanthes tetraphylla & Tree & Dambu & $\mathrm{LC}$ & 0.91 & 0.20 & 0.38 \\
\hline Sapindaceae & Sapindus trifoliata & Tree & Kahapenela & NT & - & 0.26 & 0.39 \\
\hline Sapindaceae & Schleichera oleosa & Tree & Kone & & - & 0.31 & 0.56 \\
\hline Sterculiaceae & Helicteres isora & Tree & Lihiniya & NT & - & - & 0.02 \\
\hline Sterculiaceae & Pterospermum suberifolium & Tree & Welan & $\mathrm{LC}$ & 1.84 & 11.47 & 16.73 \\
\hline Tiliaceae & Grewia damine & Tree & Damaniya & $\mathrm{LC}$ & 0.03 & 4.95 & 8.87 \\
\hline Tiliaceae & Grewia helicterifolia & Tree & Boradaminiya & LC & 0.51 & 0.04 & 0.03 \\
\hline Ulmaceae & Trema orientalis & Tree & Gadumba & & - & - & 0.01 \\
\hline Vahliaceae & Callicarpa tomentosa & Tree & Illa & $\mathrm{LC}$ & - & 0.36 & 0.01 \\
\hline Verbenaceae & Premna tomentosa & Tree & $\mathrm{Bu}$ seru & $\mathrm{LC}$ & 0.48 & 0.26 & 0.26 \\
\hline Verbenaceae & Tectona grandis & Tree & Tekka & & - & - & 0.32 \\
\hline Verbenaceae & Vitex altissima & Tree & Milla & NT & 0.05 & 0.13 & 0.11 \\
\hline
\end{tabular}

*Categories are based on final expected life form (Ashton et al., 1997)

${ }^{1}$ National Conservation Status (follows, MOE, 2012)

VU- Vulnerable; NT - Near Threatened; LC - Least Concerned 
